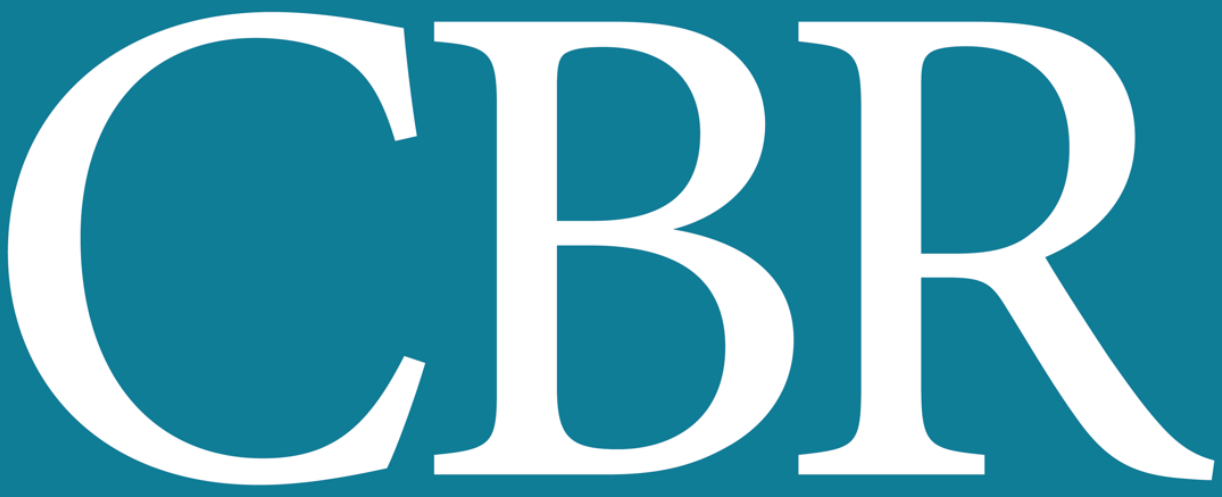

INTERNATIONAL JOURNAL OF CANCER AND BIOMEDICAL RESEARCH

https://jcbr.journals.ekb.eg

Editor-in-chief

Prof. Mohamed Labib Salem, PhD

Evaluation of HER2/neu and SPINK1 as an adjunct to the prognosis of urothelial dysplasia and urothelial carcinoma of the urinary bladder

Aliaa Atef and Asmaa Bedeer 


\section{Welcome letter from Editor-in-Chief}

Welcome to the Int J Cancer and Biomedical Research (IJCBR)!

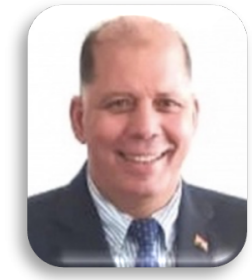

It is with great pleasure that I write this editorial to welcome you to the IJCBR. This journal provides a platform for publication of original and reviews research articles, short communications, letter to editor, thesis abstract, conference report, and case studies. These types of publication are directed at the interface of the fields of cancer and biomedical research.

The IJCBR relies on a distinguished expert of the Advisory and Editorial Board Members from the top international league covering in depth the related topics. They timely review all manuscripts and maintain highest standards of quality and scientific methodology and ethical concepts. Meanwhile, we take all possible means to keep the time of the publication process as short as possible.

I take this chance to welcome your contributions to the IJCBR and have every expectation that it will soon become one of the most respected journals in both the fields of cancer and biomedical research.

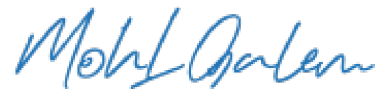

Mohamed L. Salem,

Editor in Chief 


\title{
Evaluation of HER2/neu and SPINK1 as an adjunct to the prognosis of urothelial dysplasia and urothelial carcinoma of the urinary bladder
}

\author{
Aliaa Atef and Asmaa Bedeer \\ Pathology Department, Faculty of Medicine, Tanta university, Egypt
}

\begin{abstract}
III
ABSTRACT

Background: Urinary bladder carcinoma is one of the most common malignancies worldwide. Urothelial carcinoma (UC) is the commonest type of bladder cancer and comprises $90 \%$ of all bladder primary tumors. Urothelial dysplasia (UD) points to urothelial instability and is a sign for tumor progression or recurrence, developing into UC in 5-19\% of cases. Thus, the identification of valuable markers can be useful for assessing tumor progression and response to targeted therapies. Aim: This study aimed to assess the immunohistochemical expression of HER2/neu and SPINK1 in UD and UC, and their relation to available clinicopathological parameters. Materials and methods: This study was carried out on 30 cases of UD; and 30 cases of UC. Immunohistochemistry was performed using HER2/neu and SPINK1 primary antibodies Results: HER2 expression was positive in 3 cases of carcinoma in situ (CIS) (out of 30 cases of UD) and 17 out of 30 UC cases. SPINK1 showed positive expression in $2 \mathrm{CIS}$ cases and 19 UC cases. There was a statistically significant difference in HER2 and SPINK1 expression between UD and UC. HER2 and SPINK1 expression increased significantly with the increased tumor size, grade and pathologic stage. Only HER2 expression was significantly associated with tumor recurrence. Conclusions: HER2 overexpression is closely associated with aggressive tumors. HER2 can be a valuable predictive indicator for UC prognosis selecting patients who are likely to benefit from anti HER2 targeted therapy. High SPINK1 expression also correlated with features of biologically aggressive bladder UC cases but did not have independent prognostic value.
\end{abstract}

Keywords: Bladder urothelial dysplasia, Bladder urothelial carcinoma, HER2/neu, SPINK1

Editor-in-Chief: Prof. M.L. Salem, PhD - Article DOI: 10.21608/jcbr.2020.46899.1084
AII ARTICLE INFO

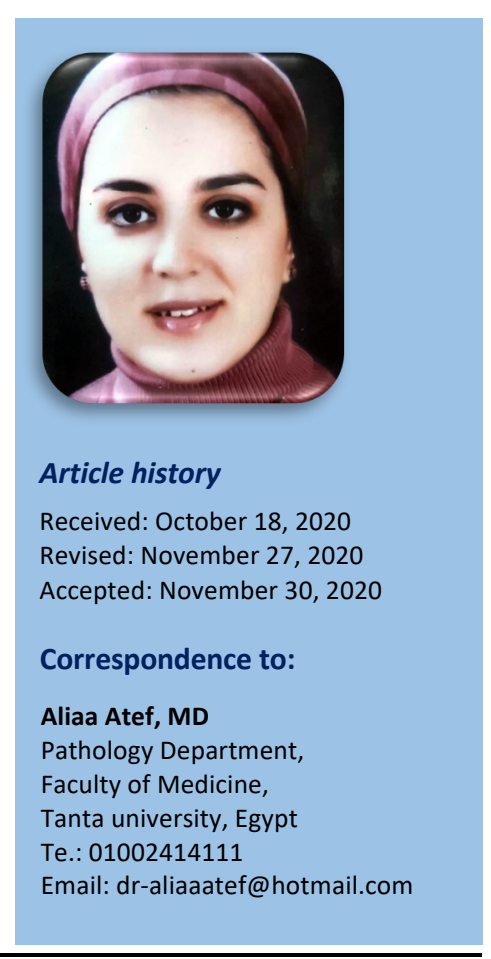

\section{INTRODUCTION}

Urinary bladder carcinoma is the third most common malignancy in males and the 11th in females worldwide (American cancer society, 2016). Urothelial carcinoma is the furthermost common type of bladder cancer and comprises about $90 \%$ of all primary tumors of the bladder (Zeng et al., 2016). In Egypt, according to the National Cancer Institute, urinary bladder neoplasm constitutes $30 \%$ of all malignancies with a frequency rate of $13.5 / 100,000$ individuals (Ibrahim et al., 2014). Dysplasia in cases with papillary noninvasive tumors points to urothelial instability and is a sign for tumor progression or recurrence. Dysplasia usually develops into urothelial carcinoma in $5-19 \%$ of cases (Barth et al., 2018).
Numerous factors affect the prognosis and treatment choice in urothelial carcinoma including patient's age, tumor grade, stage and associated carcinoma in situ. But, they may be deficient in defining the prognosis. Dissimilar outcomes may be noticed in cases of similar stage and grade (Babjuk et al., 2013).

Besides, therapeutic efforts are restricted to cases with metastasis with only little improvement. In addition, more than $75 \%$ of cases have tumor in the superficial layer of the bladder wall and nearly $20-40 \%$ of cases will present with invasive tumor later (Zheng et al., 2012). Thus, the identification of valuable biological markers can be useful for assessing the progression and the response to alternative targeted therapies (Matsushita et al., 2011). 
Human epidermal growth factor receptor 2 (HER2) is a transmembrane tyrosine kinase receptor which involved in cell growth, survival and migration. HER2 is well-known to play a role in controlling normal cellular proliferation by an intrinsic tyrosine kinase activity, amplification of the HER2/neu gene appears to play a role in neoplastic cell growth (Sanguedolce et al., 2019).

Assessment of HER2 status is critical in managing breast cancer, for prognosis and predicting the response to targeted therapies. HER2 was found to be associated with poor prognosis and response to target therapy by specific chemotherapeutic agents as trastuzumab (Badary et al., 2018). Such promising results of HER 2 in breast and other tumors as gastric cancer have motivated the investigation of HER2 expression in other cancers to deliver the usage of HER2 inhibitors (El Ochi et al., 2017).

Immunohistochemical expression of HER2 displays wide variability in different studies of urothelial carcinoma and was associated with higher grade, stage and poor prognosis (Fleischmann et al., 2011 \& Naruse et al., 2010). Though, other studies have reported no such association (Bellmunt et al., 2015). Therefore, the value of HER2 overexpression in urothelial carcinoma is still unclear.

The serine protease inhibitor Kazal type 1 (SPINK1) gene, also known as tumourassociated trypsin inhibitor (TATI) or pancreatic secretory trypsin inhibitor (PSTI), it encodes a 79 amino acid peptide, and developed SPINK1 comprises 56 amino acids (Mehner \& Radisky, 2019).

SPINK1 has $50 \%$ homology with epidermal growth factor (EGF) in the arrangements of amino acid, and so can be connected with epidermal growth factor receptor (EGFR). Consequently, it was deduced that SPINK1 has a growth factor role (Xiu et al., 2018).

Latest studies have verified that SPINK1 is a predictor of unfavorable outcomes in many tumors as prostate (Ateeq et al., 2011), colon (Ida et al., 2015 and Tiwari 2015), pancreatic (Zhang et al., 2016) and ovarian cancer (Mehner et al., 2016), and that SPINK1 induce tumorgenesis via a mechanism independent from its traditional action as a serine protease inhibitor (Shyu et al., 2019).

Previous studies proposed the probable role of SPINK1 in tumor development and progression, and that SPINK1 might be a valuable therapeutic target for cancer. However, its expression pattern and role in prognosis in urothelial carcinoma is still uncertain.

This study aimed to assess the immunohistochemical expression of HER2/neu and SPINK1 in urothelial dysplasia and urothelial bladder carcinoma, and their relation to various clinicopathological parameters.

\section{MATERIALS AND METHODS}

This study was carried out on 30 cases diagnosed as urothelial dysplasia (UD), and 30 cases diagnosed as urothelial carcinoma (UC) by two pathologists. Samples were collected as formalin-fixed, paraffin-embedded tissue blocks, with H\&E stained slides from the archives of the pathology department of faculty of medicine, Tanta University and private labs (48 cases) or received as fresh specimens taken by TRUB procedure and by radical cystectomy (12 cases) in the period from May 2019 till May 2020. Only the TRUB cases with included muscle layer were included in this study. The studied cases of urothelial carcinoma were graded according to the classification of WHO 2016 (Moch et al., 2016) and the pathological stage (depth of invasion of urothelial carcinoma) according to TNM staging system (Amin et al., 2017).

\section{Immunohistochemistry}

It was performed using the immunoperxoidase method on $4 \mu$-thick sections from the paraffinembedded blocks. Tissue sections were deparaffinized in xylene and rehydrated in descending grades of alcohol $(100,95,85$ and $75 \%$ ethanol) and blocked with $3 \%$ hydrogen peroxide for $15 \mathrm{~min}$ at room temperature. Antigen retrieval was performed after heating in citrate buffer at $98^{\circ} \mathrm{C}$ for $10 \mathrm{~min}$. Pretreated sections were incubated with mouse monoclonal HER2/neu antibody (1:100, Thermo Scientific, Egypt Catalog \# MA1-35720) and SPINK1 a rabbit polyclonal antibody (1:500, Thermo Scientific, Egypt, Catalog \# PA5-55634) 
was also applied to the sections at $4^{\circ} \mathrm{C}$ overnight and incubated with secondary antibody (HRPRabbit/Mouse) for $30 \mathrm{~min}$ at $37^{\circ} \mathrm{C}$. The signal was detected with 3,3'-diaminobenzidine solution. using a light microscope. As a negative control, a section was processed in which the primary antibody was changed by PBS. Immunohistochemical staining was evaluated independently by two pathologists.

\section{Immunohistochemical interpretation:}

Every immunohistochemically stained slide was scanned and the fields that reflect the best of the overall immunostaining were chosen and captured using light microscope attached with an imaging system (Lieca DM 2000, Lieca Microscopy and Scientific Instruments Group Germany).

HER2 expression was found to be membranous and cytoplasmic but HER2 was considered positive only with membranous staining using the ASCO scoring system. HER2 expression was assessed semi-quantitatively by the intensity and percentage of staining and scored as follows : $0=$ no staining or incomplete membranous staining in $\leq 10 \%$ of tumor cells, $+1=$ incomplete membranous staining in $>10 \%$ of tumor cells, $+2=$ circumferential, incomplete and/or weak/ moderate membranous staining in $>10 \%$ of tumor cells or complete, circumferential intense membrane staining in $\leq$ $10 \%$ of tumor cells; $+3=$ complete, intense staining of $>10 \%$ tumor cells; For statistical analysis, HER2 membranous expression score (0 and 1 ) considered negative and score (2 and 3 ) considered positive (Badary et al., 2018).

SPINK 1 showed cytoplasmic expression in tumor cells. It was evaluated semiquantitatively. The percentage of positive cells was assessed as follows: $0=$ no positive cells; $1=1-10 \%$ positive cells; $2=11-50 \%$ positive cells; $3=\geq 51 \%$ positive cells. Staining intensity was assessed as follows: $0=$ no staining; $1=$ weak staining; $2=$ moderate staining; $3=$ strong staining. SPINK 1 score $=$ staining percentage $x$ intensity. When SPINK1 expression $<2$ = low expression, $\geq 2$ = high expression (Guo et al., 2019).

Statistical analysis was performed by the SPSS software package. The relation between markers expression and the clinicopathological characteristics were analysed by Student $t$-test and Fisher's exact test. $P$-value $<0.05$ was considered statistically significant.

\section{RESULTS}

The studied cases included 30 cases of urothelial dysplasia and 30 cases of urothelial carcinoma. The sex distribution showed 34 males (10 UD and $24 \mathrm{UC}$ ); and 26 females (20 UD and 6 UC). The main age of UD cases was 40 years while the main age for UC cases was 64 years. Urothelial dysplasia cases included 19 cases of low-grade UD and 11 cases of highgrade UD (CIS). Urothelial carcinoma cases were classified according to WHO 2016 into 12 lowgrade cases ( $\mathrm{G}$ I, II) and 18 high-grade cases (G III, IV). Low-grade cases were divided into 8 cases of papillary non-invasive UC and 4 cases of low-grade invasive UC. All 18 high-grade cases were invasive UC. TNM staging of carcinoma cases showed 7 cases of pTa, 5 cases of pT1, 8 cases of pT2, 10 cases of pT3 and no cases were of pT4. Regarding disease recurrence, only 3 cases of urothelial carcinoma were recurrent and the rest were diagnosed for the first time.

\section{Immunohistochemical staining results of HER2}

All low-grade UD cases showed complete negative staining for HER2 or negative with weak incomplete focal staining of umbrella cells. High-grade UD (CIS) showed moderate to strong positivity in 3 cases (27\%) and negative staining in the 8 remaining cases (Figure 1) (Table 1). The correlation between the immunohistochemical staining results of HER2 in urothelial dysplasia cases and the clinicopathological characters were summarized in Table (2).

Regarding urothelial carcinoma cases, 17 cases (56\%) were positive for HER2 immunostaining (Figures 2, 3), with a statistically significant difference in HER2 expression between UD and UC $(p<0.001)$ (Table 1). The expression of HER2 in the nearby normal urothelium was negative or weak staining in umbrella cells. Higher grades of UC were associated with increased HER2 expression. The relation between the immunohistochemical staining results of HER2 in urothelial carcinoma cases and the clinicopathological characters were 
summarized in Table (3). A significant statistical relation was found between HER2 expression and tumor size $(p=0.018)$, tumor grade $(p=$ $0.008)$, pathologic stage $(p=0.03)$ and disease recurrence $(p=0.046)$ Table (7).

\section{Immunohistochemical staining results of SPINK 1}

All low-grade UD cases showed complete negative staining for SPINK1 or negative with weak focal staining of umbrella cells. High-grade UD (CIS) showed low SPINK1 expression in 2 cases $(18 \%)$ and negative staining in the 9 remaining cases (Figure 4) (Table 4). The correlation between the immunohistochemical staining results of SPINK1 in urothelial dysplasia cases and the clinicopathological characters were summarized in Table (5). Regarding urothelial carcinoma cases, 19 cases (63\%) were positive for SPINK1 immunostaining) (Figures 5,6). A statistically significant difference was found between SPINK1 expression in UD and UC cases $(p<0.001)$ (Table 4$)$. The expression of SPINK1 in the nearby normal urothelium was negative or weak staining in umbrella cells. Higher grades of UC were associated also with increased SPINK1 expression. The relation between the immunohistochemical staining results of SPINK1 in urothelial carcinoma cases and the clinicopathological characters were summarized in Table (6). A significant statistical relation was found between SPINK1 expression and tumor size $(\mathrm{p}=0.039)$, tumor grade $(p=$ $0.03)$ and pathological stage $(p=0.008)$ with no significant relation to disease recurrence Table (8).

The statistical analysis of the relation of HER2 and SPINK1 to disease recurrence revealed a statistically significant relation of HER2 with the disease recurrence $(p=0.046)$ while SPINK1 showed non-significant relation with recurrence $(p=0.279)$.

\section{DISCUSSION}

Urinary bladder carcinoma is a heterogeneous disease with urothelial carcinoma being the furthermost common type of bladder cancer and comprises about $90 \%$ of all primary tumors of the bladder (Zeng et al., 2016). As patients at the same grade or stage of bladder carcinoma can have a different outcome, great concern has been given to identifying novel prognostic biomarkers for better prediction of clinical outcomes and response to therapy as the usual prognostic parameters are insufficient for prognosis (Zhao et al., 2015). HER2 is one of the frequently amplified oncogenes in urinary bladder cancer and supposed to be a probable therapeutic target for it (Simon et al., 2003). It's positioned on chromosome 17q21 which encodes a transmembrane protein interacting with numerous growth factors. It is well established that overexpression of HER2 protein is a significant prognostic factor in breast carcinoma. Nevertheless, its role in urinary bladder carcinoma still unclear (Simonetti et al., 2009). In urothelial bladder carcinoma, mutations of HER2 were identified in $9 \%$ of patients. Remarkably, some of these molecular alterations are parallel to those detected in breast cancer, proposing that both tumors may have similar pathways for malignant progression (CGARN, 2014).

In the current study, immunohistochemical investigation of HER2 was done in 60 studied cases ( 30 of UD; and 30 cases of UC). Our results revealed that HER2 was positively expressed in 3 (27\%) UD cases and 17 (56\%) UC cases with a statistically significant difference in HER2 expression between UD and UC $(p<0.001)$. Our findings were in agreement with those by Mohamad et al. (2014) who reported a statistically significant increase in Her2 expression in UC cases compared with cases of UD $(P=0.02)$.

Regarding urothelial carcinoma in our study, 17 cases $(56 \%)$ showed HER2 positivity which was in agreement with other studies (Caner et al., 2008, Naik et al., 2011 and El Gehani et al., 2012). Thus, supporting the efficacy of the immunohistochemistry procedure in evaluating HER2 expression in UC. There was a wide variation in the incidence of HER2 expression in UC from $12 \%$ to $71 \%$ (El Gehani et al., 2012). Such variations are thought to be due to the difference in the applied scoring system used to assess HER2 expression, tumor heterogeneity, variability in immunohistochemistry assays, heterogeneity between kits, antibodies and interpretations of staining or cut-off values (Charfi et al., 2013). 
Table 1. The immunohistochemical staining results of HER2 in studied urothelial dysplasia and urothelial carcinoma cases:

\begin{tabular}{|c|c|c|c|c|c|c|c|c|c|}
\hline & \multicolumn{8}{|c|}{ Immunohistochemical expression of HER2 } & \multirow{3}{*}{$P$-value } \\
\hline & \multicolumn{2}{|c|}{$\begin{array}{c}0 \\
\text { (Negative) }\end{array}$} & \multicolumn{2}{|c|}{$\begin{array}{c}+1 \\
\text { (Negative) }\end{array}$} & \multicolumn{2}{|c|}{$\begin{array}{c}+2 \\
\text { (Positive) }\end{array}$} & \multicolumn{2}{|c|}{$\begin{array}{c}+3 \\
\text { (Positive) }\end{array}$} & \\
\hline & No & $\%$ & No & $\%$ & No & $\%$ & No & $\%$ & \\
\hline Urothelial dysplasia $(n=30)$ Low grade & 19 & $100 \%$ & 0 & $0 \%$ & 0 & $0 \%$ & 0 & $0 \%$ & \multirow{3}{*}{$<0.001^{*}$} \\
\hline High grade (CIS) & 3 & $27 \%$ & 5 & $45 \%$ & 2 & $18 \%$ & 1 & $10 \%$ & \\
\hline Urothelial Carcinoma $(n=30)$ & 4 & $14 \%$ & 9 & $30 \%$ & 6 & $20 \%$ & 11 & $36 \%$ & \\
\hline
\end{tabular}

*Statistically significant $(\mathrm{P}<0.05)$.

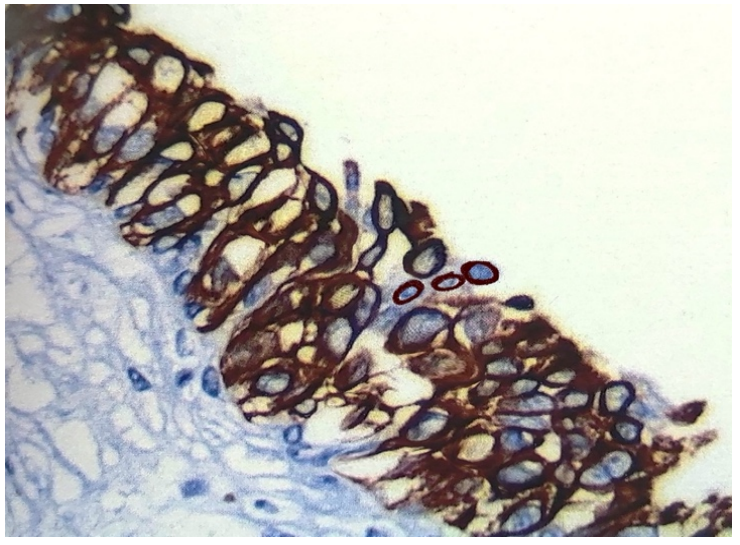

Figure 1. Urothelial carcinoma in situ showing strong $(+3)$ HER2 expression (x400)

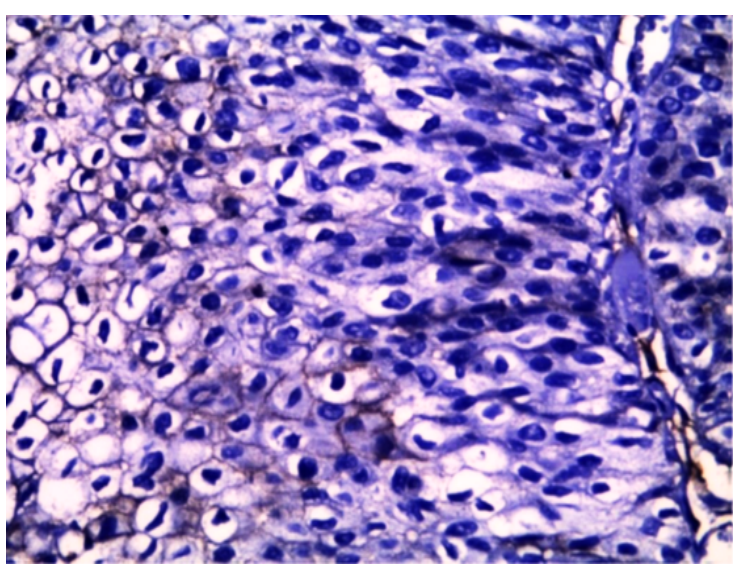

Figure 2. Low-grade urothelial carcinoma showing weak (+1) HER2 expression (x400).

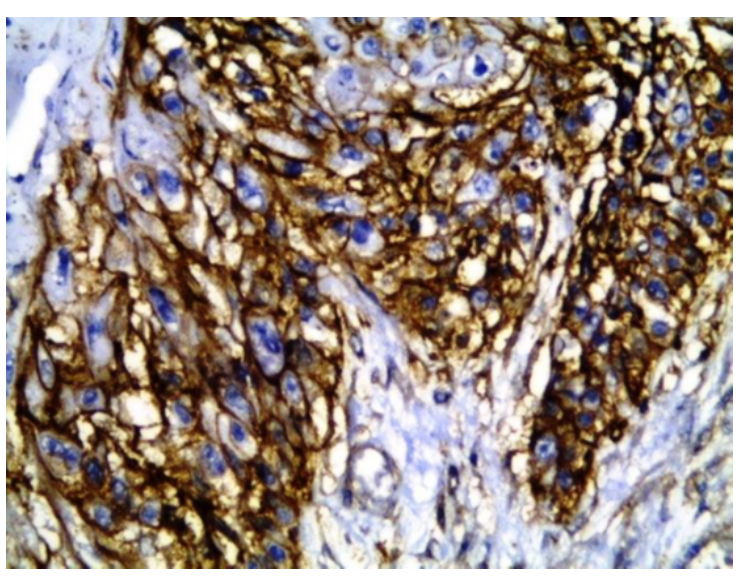

Figure 3. High-grade invasive urothelial carcinoma showing strong $(+3)$ HER2 expression (x400).
Table 2. The relation between HER2 expression and the clinical and pathological characters of studied urothelial dysplasia cases:

\begin{tabular}{|l|c|c|c|c|}
\hline Variables & $\begin{array}{c}\text { Negative } \\
\text { (0 \& +1) } \\
\mathbf{N = 2 7}\end{array}$ & $\begin{array}{c}\text { Positive } \\
(\mathbf{+ 2} \text { \& +3) } \\
\mathbf{N}=\mathbf{3}\end{array}$ & $\boldsymbol{X}^{\mathbf{2}}$ & $\boldsymbol{P}$ \\
\hline $\begin{array}{l}\text { Age } \\
\mathbf{4} \mathbf{4 0}(\mathbf{1 5 )}\end{array}$ & 14 & 1 & & $\mathbf{0 . 8 5}$ \\
$\mathbf{> 4 0}(\mathbf{1 5})$ & 13 & 2 & 0.2 & \\
\hline $\begin{array}{l}\text { Sex } \\
\text { Male (10) }\end{array}$ & 8 & 2 & & $\mathbf{0 . 5 9}$ \\
Female (20) & 19 & 1 & 0.3 & \\
\hline $\begin{array}{l}\text { Grade } \\
\text { Low grade (19) } \\
\text { High grade (11) }\end{array}$ & 19 & 0 & & \\
\hline
\end{tabular}

*Statistically significant $(\mathrm{P}<0.05) \cdot \chi 2$ : Chi-square test

Table 3. The relation between HER2 expression and the clinical and pathological characters of studied urothelial carcinoma cases:

\begin{tabular}{|c|c|c|c|c|}
\hline Variables & $\begin{array}{c}\text { Negative } \\
(0 \&+1) \\
N=13\end{array}$ & $\begin{array}{c}\text { Positive } \\
(+2 \& \\
+3) \\
N=17\end{array}$ & $x^{2}$ & $P$ \\
\hline $\begin{array}{l}\text { Age } \\
<60(14) \\
>60(16)\end{array}$ & $\begin{array}{l}7 \\
6\end{array}$ & $\begin{array}{c}7 \\
10\end{array}$ & 0.6 & 0.3 \\
\hline $\begin{array}{l}\text { Sex } \\
\text { Male (24) } \\
\text { Female (6) }\end{array}$ & $\begin{array}{c}12 \\
1\end{array}$ & $\begin{array}{c}12 \\
5\end{array}$ & 0.7 & 0.4 \\
\hline $\begin{array}{l}\text { Tumor size } \\
\quad<3 \mathrm{~cm} \\
(23) \\
>3 \mathrm{~cm}(7)\end{array}$ & $\begin{array}{c}11 \\
2\end{array}$ & $\begin{array}{c}12 \\
5\end{array}$ & 5.644 & $0.018 *$ \\
\hline $\begin{array}{l}\text { Grade } \\
\text { Low grade } \\
(12) \\
\text { High grade } \\
(18)\end{array}$ & $\begin{array}{l}8 \\
5\end{array}$ & $\begin{array}{c}4 \\
13\end{array}$ & 3.8 & $0.008 *$ \\
\hline $\begin{array}{l}\text { Pathologic } \\
\text { stage } \\
\text { pTa (7) } \\
\text { pT1 (5) } \\
\text { pT2 (8) } \\
\text { pT3 (10) }\end{array}$ & $\begin{array}{l}4 \\
2 \\
3 \\
4\end{array}$ & $\begin{array}{l}3 \\
3 \\
5 \\
6\end{array}$ & 6.3 & $0.03 *$ \\
\hline
\end{tabular}

*Statistically significant $(P<0.05) . \chi 2$ : Chi-square test 
Table 4. The immunohistochemical staining results of SPINK1 in studied cases:

\begin{tabular}{|c|c|c|c|c|c|c|c|}
\hline & \multicolumn{6}{|c|}{ Immunohistochemical expression of SPINK1 } & \multirow{3}{*}{$P$-value } \\
\hline & \multicolumn{2}{|c|}{$\begin{array}{c}\text { Score } 0 \\
\text { (Negative) }\end{array}$} & \multicolumn{2}{|c|}{$\begin{array}{c}\text { Score }<2 \\
\text { Low expression }\end{array}$} & \multicolumn{2}{|c|}{$\begin{array}{c}\text { Score }>2 \\
\text { High expression }\end{array}$} & \\
\hline & No & $\%$ & No & $\%$ & No & $\%$ & \\
\hline Urothelial dysplasia $(n=30)$ Low grade & 19 & $100 \%$ & 0 & $0 \%$ & 0 & $0 \%$ & \multirow{3}{*}{$<0.001 *$} \\
\hline High grade (CIS) & 9 & $82 \%$ & 2 & $18 \%$ & 0 & $0 \%$ & \\
\hline Urothelial Carcinoma $(n=30)$ & 11 & $37 \%$ & 7 & $23 \%$ & 12 & $40 \%$ & \\
\hline
\end{tabular}

*Statistically significant $(P<0.05)$.

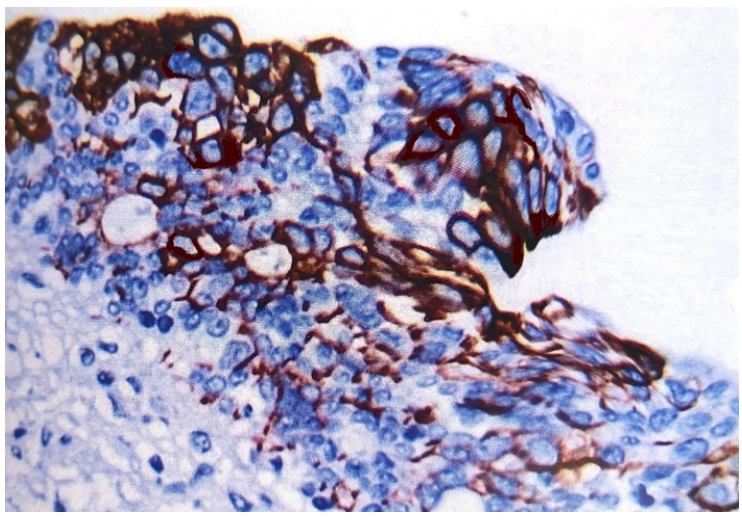

Figure 4. Urothelial carcinoma in situ showing low SPINK1 expression (Score 2) (x400)

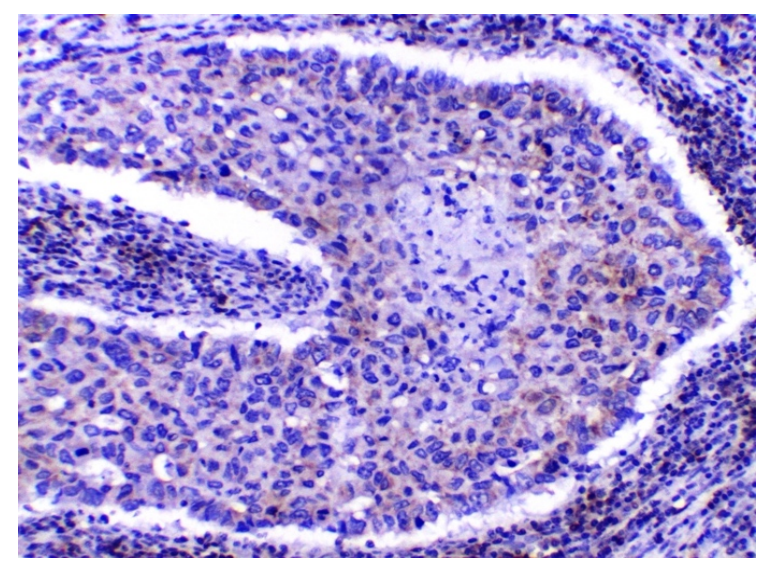

Figure 5. Low grade papillary urothelial carcinoma showing low SPINK1 expression (Score 1) (x200)

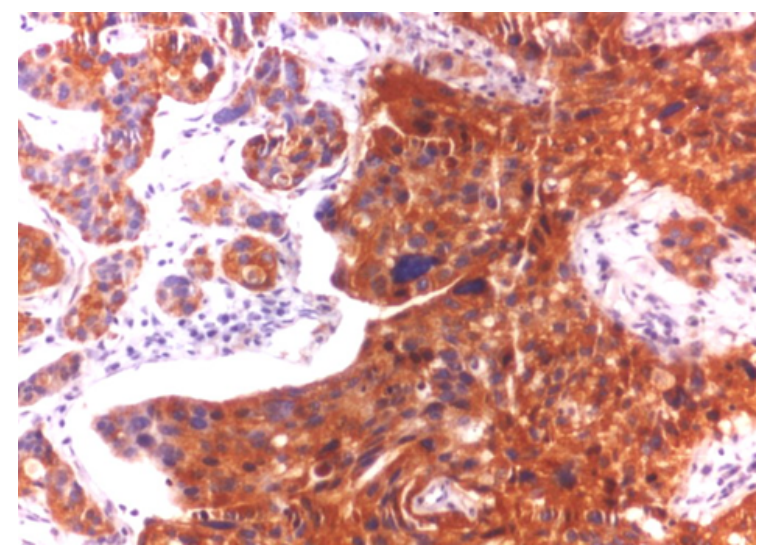

Figure 6. High grade invasive urothelial carcinoma showing high SPINK1 expression (Score 9) (x400).
Table 5. The relation between SPINK1 expression and the clinicopathological characters of studied urothelial dysplasia cases

\begin{tabular}{|l|c|c|c|c|}
\hline Variables & $\begin{array}{c}\text { Negative } \\
\mathbf{N = 2 8}\end{array}$ & $\begin{array}{c}\text { Positive } \\
\mathbf{N}=\mathbf{2}\end{array}$ & $\boldsymbol{X}^{\mathbf{2}}$ & $\boldsymbol{P}$ \\
\hline Age & 15 & 0 & & $\mathbf{0 . 7 3}$ \\
$<40(15)$ & 13 & 2 & 0.2 & \\
$>40(15)$ & & & & \\
\hline Sex & 8 & 2 & & $\mathbf{0 . 6 4}$ \\
Male (10) & 20 & 0 & 0.4 & \\
Female (20) & 19 & 0 & & $\mathbf{0 . 6}$ \\
\hline Grade & 9 & 2 & 0.35 & \\
Low grade (19) & & & & \\
High grade (11) & & & \\
\hline *Statistically signifant & & & \\
\hline
\end{tabular}

*Statistically significant $(P<0.05) \cdot \chi 2$ : Chi-square test

Table 6 . The relation between SPINK1 expression and the clinicopathological characters of studied urothelial carcinoma cases

\begin{tabular}{|c|c|c|c|c|}
\hline Variables & $\begin{array}{c}\text { Negative } \\
\mathbf{N}=11\end{array}$ & $\begin{array}{c}\text { Positive } \\
\mathrm{N}=19\end{array}$ & $x^{2}$ & $P$ \\
\hline $\begin{array}{l}\text { Age } \\
<60(14) \\
>60(16)\end{array}$ & $\begin{array}{l}7 \\
4\end{array}$ & $\begin{array}{c}7 \\
12\end{array}$ & 0.2 & 0.8 \\
\hline $\begin{array}{l}\text { Sex } \\
\text { Male (24) } \\
\text { Female (6) }\end{array}$ & $\begin{array}{c}10 \\
1\end{array}$ & $\begin{array}{c}14 \\
5\end{array}$ & 1.7 & 0.2 \\
\hline $\begin{array}{l}\text { Tumor size } \\
<3 \mathrm{~cm}(23) \\
>3 \mathrm{~cm}(7)\end{array}$ & $\begin{array}{l}7 \\
4\end{array}$ & $\begin{array}{c}16 \\
3\end{array}$ & 4.272 & $0.039 *$ \\
\hline $\begin{array}{l}\text { Grade } \\
\text { Low grade } \\
(12) \\
\text { High grade } \\
(18)\end{array}$ & $\begin{array}{l}8 \\
3\end{array}$ & $\begin{array}{c}4 \\
15\end{array}$ & 4.4 & $0.03^{*}$ \\
\hline $\begin{array}{l}\text { Pathologic } \\
\text { stage } \\
\text { pTa (7) } \\
\text { pT1 (5) } \\
\text { pT2 (8) } \\
\text { pT3 (10) }\end{array}$ & $\begin{array}{l}5 \\
3 \\
1 \\
2\end{array}$ & $\begin{array}{l}2 \\
2 \\
7 \\
8\end{array}$ & 3.9 & $0.008 *$ \\
\hline
\end{tabular}

*Statistically significant $(\mathrm{P}<0.05) \cdot \chi 2$ : Chi-square test 
Table 7. The relation between HER2 expression and the recurrence of all studied cases:

\begin{tabular}{|c|c|c|c|c|c|c|}
\hline \multirow{3}{*}{ Recurrence } & \multicolumn{4}{|c|}{ HER2 expression } & \multirow{3}{*}{$x^{2}$} & \multirow{3}{*}{$\boldsymbol{P}$} \\
\hline & \multicolumn{2}{|c|}{$\begin{array}{c}\text { Negative } \\
(n=40)\end{array}$} & \multicolumn{2}{|c|}{$\begin{array}{c}\text { Positive } \\
(n=20)\end{array}$} & & \\
\hline & no. & $\%$ & no. & $\%$ & & \\
\hline $\begin{array}{c}\text { Recurrent } \\
(n=3)\end{array}$ & 0 & $0 \%$ & 3 & $100 \%$ & 6.172 & $\begin{array}{c}0.046 \\
*\end{array}$ \\
\hline $\begin{array}{c}\text { Non } \\
\text { recurrent } \\
(n=57)\end{array}$ & 40 & $49.3 \%$ & 17 & $50.7 \%$ & & \\
\hline
\end{tabular}

*Statistically significant $(\mathrm{P}<0.05) \cdot \chi 2$ : Chi-square test

Table 8. The relation between SPINK1 expression and the recurrence of all studied cases:

\begin{tabular}{|c|c|c|c|c|c|c|}
\hline \multirow{3}{*}{ Recurrence } & \multicolumn{4}{|c|}{ SPINK1 Expression } & \multirow{3}{*}{$x^{2}$} & \multirow{3}{*}{$\boldsymbol{P}$} \\
\hline & \multicolumn{2}{|c|}{$\begin{array}{c}\text { Negative } \\
(n=39)\end{array}$} & \multicolumn{2}{|c|}{$\begin{array}{c}\text { Positive } \\
(n=21)\end{array}$} & & \\
\hline & no. & $\%$ & no. & $\%$ & & \\
\hline $\begin{array}{l}\text { Recurrent } \\
\quad(n=3)\end{array}$ & 2 & $66.7 \%$ & 1 & $33.3 \%$ & & \\
\hline $\begin{array}{c}\text { Non } \\
\text { recurrent } \\
(n=57)\end{array}$ & 37 & $35.8 \%$ & 20 & $64.2 \%$ & 1.17 & 0.279 \\
\hline
\end{tabular}

Interestingly, in a study by Bellmunt et al. (2015) they use the same procedures in the same laboratories and same scoring manner but there were significant differences between the two groups studied (Spanish and Greek population), as $27 \%$ and $4 \%$ had HER2 overexpression, respectively. So such difference observed suggests that HER2 status differs among populations, and indicates that there is considerable etiologic heterogeneity in bladder cancer.

Our results revealed a statistically significant relation between HER2 expression and the grading_of UC cases $(p=0.008)$, as increased HER2 expression was seen in higher UC grades. Also, Mohamed et al. (2017), Charfi et al. (2013) and Alexa et al. (2010) reported HER2 overexpression in high-grade UC cases compared to low-grade ones with statistical significance values, so they documented that HER2 overexpression was considerably linked to the tumor differentiation. These findings propose that HER2 overexpression might associate with more aggressive disease.

Also, a statistically significant relation ( $P=0.03$ ) was identified between HER2 expression and the staging of UC in the current work, as increased HER2 expression (scores +2 and +3 ) was identified in more advanced stages ( $p$ T2,3).
Supporting our results, Kruger et al. (2002), Jalali et al. (2007) and Charfi et al. (2013) who reported HER2 overexpression in high stages of UC than in low stages suggesting its association with more advanced disease, so evaluation of Her2 status can be useful in identifying patients at increased risk of disease progression.

In contrast with our results, loachim et al. (2000) did not find any significant relation between HER2 overexpression and UC grading or staging ( $P>0.05)$. Also, Latif et al. (2004) did not detect any significant relation between HER2 expression and tumors grade; however, HER-2 overexpression was higher in invasive tumors signifying anti-HER2 therapy for invasive cases. Likewise, Alexa et al. (2010) found no association between HER2 overexpression and the tumor stage and lymph node status as well. Such conflicting results may be due to the heterogeneity between antibodies, protocols, interpretations of HER2 expression.

Additionally, a statistically significant relation was detected between HER2 expression and tumor size $(p=0.018)$ in the current study, as high HER2 expression (scores +2 and +3 ) was seen often in cases with tumor size $>3 \mathrm{~cm}$. On the contrary, Lim et al. (2015), El Ochi et al. (2017) and Li et al. (2018) found no significant relation between HER2 overexpression and the tumor size in their work.

Furthermore, the current work revealed a statistically significant relation between HER2 expression and the recurrence of UC $(P=0.046)$ our finding was similar to those reported by $\mathrm{Li}$ et al. (2018) they noted increased HER2 expression in the recurrent group than the primary tumor group which suggest a possible prognostic role of HER2 in UC cases.

In a univariate analysis by Lim et al. (2015), they illustrated that tumor size and HER2 overexpression were significantly correlated with recurrence-free survival. In addition, in their multivariate analysis, HER2 overexpression revealed shorter recurrence time in cases with non- muscle invasive bladder cancer. In another study by Tsai et al. (2005) they found that tumor recurrence within the bladder was significantly correlated to HER2 overexpression and ureteral tumor involvement. They also stated in a multivariate 
analysis that HER2 overexpression and high grade of UC were also associated with a shorter recurrence time.

Sasaki et al. (2014) stated that overexpression of HER2 was significantly associated with shorter recurrence of $\mathrm{UC}$ in the residual bladder after nephroureterectomy and HER2 was proposed to be an independent prognostic marker for early recurrence of UC in the residual bladder after nephroureterectomy and the residual bladder should be inspected after the operation by a short time. On the contrary, in a study by Olsson et al. (2012) they did not detect any significant association between HER2 expression and prognosis including recurrence and progression of the tumor.

In this work, no statistically significant relation could be noticed between HER2 expression and patients' age and sex in all studied cases. Also, no statistically significant relation could be detected between HER2 expression and grading of UD cases. Similarly, in a study by Mohamad et al. (2014) and Nini et al. (2020) no statistically significant relation was reported regarding age and sex with respect to HER2 overexpression in their studied cases.

A promising new moleculer biomarker, Serine peptidase inhibitor Kazal type 1 (SPINK1) also known as tumor-associated trypsin inhibitor (TATI) plays an important role in inflammation, cell proliferation, and carcinogenesis. SPINK1 has been found in a wide range of different tissues, including the urothelium. Altered SPINK1 expression was noticed in different epithelial malignancies such as lung, liver, ovarian, pancreatic, colorectal and prostate carcinomas) which was associated with poor prognosis. However, few studies discussed the expression of SPINK1 in urinary bladder malignancy (Guo et al., 2019).

In the present study, we noticed a significant difference between SPINK1 expression in UC and UD. SPINK1 expression was positive in 19 cases $(63 \%)$ of UC while weak positivity was restricted to 2 cases of urothelial carcinoma in situ with a statistically significant difference between UC and UD ( $p>0.001)$. The degree of SPINK1 positivity was significantly correlated with the grade $(p=0.03)$ and pathologic stage of
UC ( $p=0.008)$. SPINK1 was negative in normal urothelium and low-grade dysplasia.

SPINK1 expression was investigated in many cancers as the pancreas (Ozaki et al., 2009), colorectal (Koskensalo et al., 2013), hepatocellular (Marshall et al., 2013), lung (Guo et al., 2019), breast (Soon et al., 2011), ovary (Mehner et al., 2015) and prostate cancers (Ateeq et al., 2015). Most of these studies confirmed the association of high SPINK1 expression with higher tumor grades, higher pathologic stages and poorer prognosis.

However, very few studies discussed the role of SPINK1 in UC and UD and its relation to prognosis especially using SPINK1 immunohistochemistery. The results of these studies were controversial. A number of these studies agreed with our results as a study by Itkonen \& Stenman (2014) who discovered that over-expression of SPINK1 predicts an unfavorable tumor outcome and serum SPINK1 can identify patients with increased risk of aggressive disease. They explained that SPINK1 acts as an autocrine transforming factor involved in progression, invasion and metastatic spread. Recently, Matuszczak \& Salagierski (2020) similarly stated that SPINK1 is produced at lower concentrations in many healthy tissues and high concentrations by several tumors such as urologic cancers.

In 2003, Kelloniemi et al. showed that SPINK1 might be valuable for the identification of patients with adverse prognosis in transitional cell carcinoma. They suggested that SPINK1 (TATI) is expressed together with tumorassociated trypsin which recently was found to activate prourokinase and collagenases responsible for tumor invasion (matrix metalloproteinase-2 and metalloproteinase-9). Elevated TATI concentrations in serum reflect trypsinogen expression in the tumor. This gives a logical explanation for the prognostic value of SPINK1 in some cancers including bladder cancer.

Later Shariat et al. (2005) demonstrated that urinary SPINK1 levels were significantly higher in TCC patients than in control group and higher levels of SPINK1 in urine can correlate with the risk of bladder tumour, increased tumor size and tumor stage. Another study was done by 
Gkialas et al. (2008) found that SPINK1 measurements were significantly greater in the group of urothelial carcinomas compared with the normal control group or the group of benign bladder lesions and considered SPINK1 a promising more sensitive urinary tumor marker for high-grade urothelial bladder carcinoma.

On the other hand, other studies reached different results as found in a study by Patschan et al. (2012). Interestingly, they noted that SPINK1 was expressed in $100 \%$ of patients without cancer (unlike our results), while $71 \%$ of radical cystectomy showed decreased or no SPINK1 expression. SPINK1 level showed a positive correlation with bladder tumors of favourable differentiation. SPINK1 expression also decreased with advancing pathological stage. They suggested that SPINK1 plays an important role in pathogenesis and invasion of urothelial carcinoma. Its association with markers involved in the cell cycle, proliferation and inflammation serve as a hypothesis for molecular interactions. They explained their results by misbalance between the tissueprotective effect of SPINK1 as an inhibitor of trypsin and the tissue destructive effect of trypsinogen. This was the same as the results of Hotakainen et al. (2006) who reported that SPINK1 expression was found in all non-invasive tumors and benign tissues, but the expression was lower in the muscle-invasive tumors and that SPINK1 expression decreased with the rising stage and grade of bladder tumor.

Similarly Rink et al. (2013) reported that a loss of SPINK1 expression was noted in $57.9 \%$ of UC cases and was significantly associated with higher tumor grades and pathologic stages. As in our study, SPINK1 expression was found in umbrella cells of $52 \%$ of control cases in the normal urothelium. Lately Liu et al. (2019) made a similar conclusion that a decreased SPINK1 expression correlated with more advanced disease and was positively correlated with favorable differentiation of bladder cancer, and lower tumor stage. These discrepancies of results between our study along with several others on one hand, and between other studies with different findings, on the other hand, can be explained by differences in the reliability of immunohistochemical techniques. Immunohistochemistry is a semiquantitative process and dependent on many variables, such as the choice of antibodies, antibody concentration, fixation techniques, subjectivity of interpretation and stratification criteria, and inconsistency of specimen handling and technical procedures. It can also be attributed to the different populations of bladder cancer patients (Rink et al., 2013).

In addition, our study found that positive SPINK1 expression was related to poor prognosis of bladder UC despite being not significantly correlated with tumor recurrence $(p=0.279)$ which was not the case for HER2. This can be attributed to the relatively small sample size and short duration of the study. Many studies confirmed the association of SPINK1 positivity and poor prognosis and tumor recurrence. Kelloniemi et al. (2003) stated that SPINK1 is potentially useful for the identification of patients with an adverse prognosis and considered it an independent prognostic factor in transitional cell carcinoma.

Later on, Patschan et al. (2012) confirmed that a decreased level of SPINK1 was associated with high recurrences and cancer-specific mortality. Afterwards, Rink et al. in 2013 also noted that loss of SPINK1 expression was associated with increased risk of disease recurrence and cancerspecific mortality but like our results, statistical analyses revealed that SPINK1 is not an independent predictor of disease recurrence $(P$ 0.09) or cancer-specific mortality $(P=0.12)$. Similarly, Itkonen \& Stenman (2014) observed the association of high tissue expression of SPINK1 with poor prognosis.

Recently, Mehner \& Radisky stated that SPINK1 positive cases of bladder UC face a poorer overall prognosis (Mehner \& Radisky, 2019).

\section{CONCLUSION}

HER2 overexpression is closely associated with cases with aggressive disease (high grade, advanced stage and recurrence) and so merits consideration. HER2 can be a valuable predictive indicator for UC prognosis that could assist in selecting patients who are likely to benefit from anti-HER2 targeted therapy. High SPINK1 expression also correlated with features of biologically aggressive bladder urothelial carcinoma cases except for tumor recurrence. 
Unlike HER2, SPINK1 expression did not have independent prognostic value, maybe due to small sample size, but it may serve as a biomarker for tumor staging along with HER2 and may be useful as an adjunct in clinical decision-making. The statistically significant difference in HER2 and SPINK1 expression between UD and UC can be useful in the diagnostic differentiation between the two entities but more studies are recommended for their validation.

\section{CONFLICTS OF INTEREST}

All authors declared no conflicts of interest.

\section{FUNDING}

No fund was received for this work.

\section{REFERENCES}

Alexa A, Baderca F, Zăhoi DE, Lighezan R, Izvernariu D, Raica M. (2010). Clinical significance of Her2/neu overexpression in urothelial carcinomas. Rom J Morphol Embryol. 51: 277282.

American cancer society (2017). Cancer facts and figures. Atlanto, GA: American Cancer society 2016.

Amin MB, Edge SB. AJCC cancer staging manual $\left(8^{\text {th }}\right.$ edition). Springer, New York, USA.

Ateeq B, Tomlins SA, Laxman B, Asangani IA, Cao Q, Cao X, Li Y, Wang $X$, Feng FY, Pienta KJ, Varambally S. (2011). Therapeutic targeting of SPINK1-positive prostate cancer. Sci. Transl. Med. 3, 72ra17.

Babjuk M, Burger M, Zigeuner R, Shariat SF, van Rhijn BW, Compérat E (2013). European Association of Urology. EAU guidelines on non-muscleinvasive urothelial carcinoma of the bladder. Eur Urol. 64: 639-653.

Badary DM, El Refaiy A, Sotohy T, Nassar M, Hafez M, Reda A. (2018). Comparative Immunohistochemical Study of Expression of FGFR3, HER2, COX2 in Transitional Cell Carcinoma vs. the Adjacent Urothelial Precancerous Changes. Ann Clin Pathol Res. 1: 1003.

Barth I, Schneider U, Grimm T, Karl A, Horst D, Gaisa NT, Knüchel R, Garczyk S. (2018). Progression of urothelial carcinoma in situ of the urinary bladder: a switch from luminal to basal phenotype and related therapeutic implications. Virchows Archiv. 472: 749-758.

Bellmunt J, Werner L, Bamias A, Fay AP, Park RS, Riester M, Selvarajah S, Barletta JA, Berman DM, de Muga S, Salido M. (2015). HER2 as a target in invasive urothelial carcinoma. Cancer Med. 4: 844-52.

Cancer Genome Atlas Research Network (2014). Comprehensive molecular characterization of urothelial bladder carcinoma (CGARN). Nature; 507: 315-22.

Caner V, Turk NS, Duzcan F, Tufan NL, Kelten EC, Zencir S, Dodurga Y, Bagci H, Duzcan SE. (2008). No strong association between HER-2/neu protein overexpression and gene amplification in high-grade invasive urothelial carcinomas. Pathol. Oncol. Res. 14: 261-266.

Charfia S., Khabir A., Mnifa H., Ellouzea S., Mhirib M., Sellamia T. (2013). Immunohistochemical expression of HER2 in urothelial bladder carcinoma and its correlation with p53 and p63 expression. J Microsc Ultrastruct. 1:17-21.

El Gehani J, Al-Kikhia L, Emaetig F, Syrjanen K, AlFituri O, Elzagheid A. (2012). Over-expression of HER-2 is associated with the stage in carcinomas of the urinary bladder. Libyan J Med. 7: 14694.

El Ochi1 MR, Oukabli M, Bouaiti E, Chahdi $H$, Boudhas A, Allaoui M, Ameur A, Abbar M and Al Bouzidi A. (2017). Expression of human epidermal growth factor receptor 2 in bladder urothelial carcinoma. BMC Clinical Pathology. 17: 3.

Fleischmann A, Rotzer D, Seiler R, Studer UE, Thalmann GN. (2011). Her2 amplification is significantly more frequent in lymph node metastases from urothelial bladder cancer than in the primary tumours. Eur Urol. 60: 350-357.

Gkialas I, Papadopoulos G, Iordanidou L, Stathouros G, Tzavara C, Gregorakis A, Lykourinas M. (2008). Evaluation of urine tumor-associated trypsin inhibitor, CYFRA 21-1, and urinary bladder cancer antigen for detection of highgrade bladder carcinoma. Urology. 72: 11591163.

Guo M, Zhou X, Han X, Zhang Y, Jiang L. (2019). SPINK1 is a prognosis predicting factor of non-small cell lung cancer and regulates redox homeostasis. Oncology Letters. 18: 6899-908.

Hotakainen K, Bjartell A, Sankila A, Järvinen R, Paju A, Rintala E, Haglund C, Stenman UH. (2006). Differential expression of trypsinogen and tumor-associated trypsin inhibitor (TATI) in bladder cancer. International journal of oncology. 28: 95-101.

Ibrahim AS, Khaled HM, Mikhail N H, Baraka $\mathrm{H}$ and Kamel H. (2014). Cancer Incidence in Egypt: Results of the National Population-Based Cancer Registry Program. Journal of Cancer Epidemiology. 18.

Ida S, Ozaki N, Araki K (2015). SPINK1 status in colorectal cancer, impact on proliferation, and 
role in colitis-associated cancer. Mol Cancer Res. 13: 1130-1138

loachim E, Charchanti A, Stavropoulos N E, Skopelitou A, Athanassiou E D and Agnantis N J. (2000). Immunohistochemical expression of retinoblastoma gene product $(\mathrm{Rb}), \mathrm{p} 53$ protein, MDM2, c-erbB-2, HLA-DR and proliferation indices in human urinary bladder carcinoma. Histol Histopathol. 15: 721-727.

Itkonen O and Stenman UH.( 2014). TATI as a biomarker. Clin Chim Acta. 431, 260-269.

Jalali Nadoushan MR, Taheri T, Jouian N, Zaeri F. (2007). Overexpression of HER-2/- neu oncogene and transitional cell carcinoma of bladder. Urol J. 4: 151-154.

Badary DM, El Refaiy A, Sotohy T, Nassar M, Hafez M, (2018). Reda A. Comparative Immunohistochemical Study of Expression of FGFR3, HER2, COX2 in Transitional Cell Carcinoma vs. the Adjacent Urothelial Precancerous Changes. Ann Clin Pathol Res. 1: 1003.

Kelloniemi E, Rintala E, Finne P, Stenman UH, (2003). Finnbladder Group. Tumor-associated trypsin inhibitor as a prognostic factor during follow-up of bladder cancer. Urology. 62: 249-253.

Krüger $S$, Weitsch $G$, Büttner $H$, Matthiensen $A$, Böhmer T, Marquardt T, Sayk F, Feller AC, Böhle A. (2002). HER2 overexpression in muscleinvasive urothelial carcinoma of the bladder: Prognostic implications. Int. J. Cancer. 102: 514518.

Latif Z, Watters AD, Dunn I, Grigor K, Underwood MA, Bartlett JM. (2004). HER2/neu gene amplification and protein overexpression in $\mathrm{G} 3$ pT2 transitional cell carcinoma of the bladder: a role for anti-HER2 therapy? Eur J Cancer. 40: 56-63.

Li W, Wang Y, Tan S, Rao Q, Zhu T, Huang G, Li Z, Liu G. (2018). Overexpression of EGFR and HER-2 in bladder carcinoma and Its Association with Patients' Clinical Features. Med Sci Monit, 24: 7178-7185.

Lim SD, Cho YM, Choi GS, Park HK, Paick SH, Kim WY, Kim SN, Yoon G. (2015). Clinical significance of substaging and HER2 Expression in papillary nonmuscle invasive urothelial cancers of the urinary bladder. J Korean Med Sci. 30: 1068-77.

Liu A, Xue $Y$, Liu F, Tan $H$, Xiong Q, Zeng S, Zhang Z, Gao X, Sun Y, Xu C. (2019). Prognostic value of the combined expression of tumor-associated trypsin inhibitor (TATI) and p53 in patients with bladder cancer undergoing radical cystectomy. Cancer Biomarkers. 26: 281-289.

Matsushita K, Cha EK, Matsumoto K, Baba S, Chromecki TF, Fajkovic H, Sun M, Karakiewicz PI, Scherr DS, Shariat SF. (2011).
Immunohistochemical biomarkers for bladder cancer prognosis. Int. J. Urol. 18: 616-629.

Matuszczak M, Salagierski M. (2020). Diagnostic and Prognostic Potential of Biomarkers CYFRA 21.1, ERCC1, p53, FGFR3 and TATI in Bladder Cancers. International Journal of Molecular Sciences. 2 :3360.

Mehner C, Oberg AL, Kalli KR, Nassar A, Hockla A, Pendlebury D, Cichon MA, Goergen KM, Maurer MJ, Goode EL, Keeney GL. (2015). Serine protease inhibitor Kazal type 1 (SPINK1) drives proliferation and anoikis resistance in a subset of ovarian cancers. Oncotarget. 6: 35737-35754.

Mehner C, Radisky ES. (2019). Bad tumors made worse: SPINK1. Frontiers in cell and developmental biology. 7: 10.

Moch H, Humphrey PA, Ulbright TM, Reuter VE. (2016). WHO classification of tumours of the urinary system and male genital organs. International Agency for Research on Cancer (IARC).

Mohamad AY, El-Esawy B H. (2014). Her2/neu expression in urothelial dysplasia, carcinoma in situ, and superficial urothelial carcinoma and its value in assessing the response to BCG therapy. Egyptian Journal of Pathology. 34: 25-31.

Mohamed A, Ramadan M, Helmy O, Mohamed S. (2017). Immunohistochemical expression of CD10 and HER-2/NEU in urothelial carcinoma versus chronic cystitis in Zagazig University hospitals (retrospective study). Zagazig University Medical Journal. 23: 1-8.

Naik DS, Sharma S, Ray A and Hedau S. (2011). Epidermal growth factor receptor expression in urinary bladder cancer. Indian J Urol. 27: 208214.

Naruse K, Yamada Y, Nakamura K, Aoki S, Taki T, Zennami K, Katsuda R, Watanabe M, Nishikawa G, Itoh Y, Mitsui K. (2010). Potential of molecular targeted therapy of HER-2 and Cox-2 for invasive transitional cell carcinoma of the urinary bladder. Oncology Reports.23: 1577-83.

Nini A, Hoffmann MJ, Lampignano R, große Siemer R, van Dalum G, Szarvas T, Cotarelo CL, Schulz WA, Niederacher D, Neubauer $\mathrm{H}$, Stoecklein $\mathrm{NH}$. (2020). Evaluation of HER2 expression in urothelial carcinoma cells as a biomarker for circulating tumor cells. Cytometry Part B: Clinical Cytometry. 25.

Olsson H, Fyhr IM, Hultman P, Jahnson S. (2012). HER2 status in primary stage T1 urothelial cell carcinoma of the urinary bladder. Scand J Urol Nephrol. 46: 102-7.

Patschan O, Shariat SF, Chade DC, Karakiewicz PI, Ashfaq R, Lotan Y, Hotakainen K, Stenman UH, Bjartell A. (2012). Association of tumor- 
associated trypsin inhibitor (TATI) expression with molecular markers, pathologic features and clinical outcomes of urothelial carcinoma of the urinary bladder. World journal of urology. 30: 785-794.

Rink M, Park K, Volkmer BG, Xylinas E, Hansen J, Cha EK, Robinson BD, Hautmann R, Küfer R, Engel O, Chun FK. (2013). Loss of SPINK1 expression is associated with unfavorable outcomes in urothelial carcinoma of the bladder after radical cystectomy. In Urologic Oncology: Seminars and Original Investigations. 31: 17161724.

Sanguedolce F, Russo D, Mancini V, Selvaggio O, Calo B, Carrieri G, Cormio L. (2019). Prognostic and therapeutic role of HER2 expression in micropapillary carcinoma of the bladder. Molecular and Clinical Oncology. 10: 205-13.

Sasaki Y, Sasaki T, Kawai T, Morikawa T, Matsusaka K, Kunita A, Kume H, Aoki I, Homma Y, Fukayama M. (2014). HER2 protein overexpression and gene amplification in upper urinary tract urothelial carcinoma-an analysis of 171 patients. Int J Clin Exp Pathol. 7: 699-708.

Shariat SF, Herman MP, Casella R, Lotan Y, Karam JA, Stenman UH. (2005). Urinary levels of tumorassociated trypsin inhibitor (TATI) in the detection of transitional cell carcinoma of the urinary bladder. European urology.48: 424-431.

Shyu RY, Wang CH, Wu CC, Wang LK, Chen ML, Kuo CY, Lee MC, Lin YY and Tsai FM. (2019). Tazarotene-Induced Gene 1 (TIG1) Interacts with Serine Protease Inhibitor Kazal-Type 2 (SPINK2) to Inhibit Cellular Invasion of Testicular Carcinoma Cells. BioMed Research International. Article ID 6171065, 10 pages

Simon R, Atefy R, Wagner U, Forster T, Fijan A, Bruderer J, Wilber K, Mihatsch MJ, Gasser T, Sauter G. (2003). HER-2 and TOP2A coamplification in urinary bladder cancer. Int J Cancer.107: 764-772.
Simonetti S, Russo R, Ciancia G, Altieri V, De Rosa G, Insabato L. (2009). Role of- polysomy 17 in transitional cell carcinoma of the bladder: immunohisto-chemical study of HER2/neu expression and fish analysis of c-erbB-2 gene and chromosome 17. Int J Surg Pathol. 17:198205.

Tiwari R, Pandey SK, Goel S, Bhatia V, Shukla S, Jing X, Dhanasekaran SM, Ateeq B. (2015). SPINK1 promotes colorectal cancer progression by downregulating Metallothioneins expression. Oncogenesis. 4: e162.

Tsai YS, Tzai TS, Chow NH, Wu CL. (2005). Frequency and clinicopathologic correlates of ErbB1, ErbB2, and ErbB3 immunoreactivity in urothelial tumors of upper urinary tract. Urology. 66:1197-202.

Xu L, Lu C, Huang Y, Zhou J, Wang X, Liu C, Chen J \& Le H (2018). SPINK1 promotes cell growth and metastasis of lung adenocarcinoma and acts as a novel prognostic biomarker. BMB Rep. 51: 648-653.

Zeng FC, Cen S, Tang ZY, Kang XL. (2016). Elevated matrix metalloproteinase- 9 expression may contribute to the pathogenesis of bladder cancer. Oncol Lett. 11:2213-2222.

Zhang J, Wang D, Hu N, Wang Q, Yu S, Wang J. (2016). The construction and proliferative effects of a lentiviral vector capable of stably overexpressing SPINK1 gene in human pancreatic cancer AsPC-1 cell line. Tumor Biol. 37: 5847-5855.

Zhao J, Xu W, Zhang Z, Song R, Zeng S, Sun Y, Xu C. (2015). Prognostic role of HER2 expression in bladder cancer: a systematic review and metaanalysis. Int Urol Nephrol. 47: 87-94.

Zheng YL, Amr S, Doa'a AS, Dash C, Ezzat S, Mikhail NN, Gouda I, Loay I, Hifnawy T, Abdel-Hamid M, Khaled H. (2012). Urinary bladder cancer risk factors in Egypt: a multicenter case-control study. Cancer Epidemiol Biomarkers Prev. 21: 537-546. 


\section{Egyptian Association for Cancer Research (EACR)}

http://eacr.tanta.edu.eg/

EACR is an NGO society that was declared by the Ministry of Social Solidarity (Egypt) No. 1938 in 19/11/2014 based on the initiative of Prof. Mohamed Labib Salem, the current Chairman of EACR. EACR aims primarily to assist researchers, in particular young researchers in the field of cancer research through workshops, seminars and conferences. Its first international annual conference entitled "Anti-Cancer Drug Discovery" was successfully organized in April 2019 (http://acdd.tanta.edu.eg). Additionally, EACR aims to raise the awareness of the society about the importance of scientific research in the field of cancer research in prediction, early diagnosis and treatment of cancer. EACR is also keen to outreach the scientific community with periodicals and news on cancer research including peer-reviewed scientific journals for the publication of cutting-edge research. The official scientific journal of EACR is "International Journal of Cancer and biomedical Research (IJCBR: https://jcbr.journals.ekb.eg) was successfully issued in 2017 and has been sponsored by the Egyptian Knowledge Bank (EKB: www.ekb.eg).

\section{EACR Chairman,}

Prof. Mohamed Labib Salem, PhD

Professor of Immunology

Faculty of Science, Tanta Universiy, Egypt 


\section{GUIDE FOR AUTHORS}

Publisher :The International Journal of Cancer and Biomedical Research (IJCBR) is an International and interdisciplinary journal of preclinical and clinical studies in the area of cancer and biomedical research. It is a peer-reviewed journal in English, published quarterly (in March, June, September, and December) by the Egyptian Association for Cancer Research (EACR) in both print and online formats (4 issues making a volume). Special issues or supplements may also be produced from time to time upon agreement with the Editorial Board.

Scope :The main aim of IJCBR is to attract the best research in animal and human biology in health and diseases from across the spectrum of the biomedical sciences at the molecular, cellular, organ, and whole animal levels especially those that are related to cancer research, including causes, prediction, diagnosis, prognosis, and therapy.

Publication Fees :The journal does charge for submission, processing, or publication of manuscripts (2000 LE for Egyptians or $250 \$$ for non-Egyptians; EACR members receive 15\% discount on publication). Of them Peer-review fees (300 LE) should be paid on submission (non-refundable). For the fast-track production of the accepted manuscript, another 500 LE is paid.

General specifications for different types of article

- Submitted manuscripts should not have been published previously, except in a limited form (e.g. short communication to a symposium or as part of MSc or PhD theses) and should not be under consideration for publication by other journals.

- All co-authors should agree with the content of the manuscript. Authors must have obtained permission to use any copyrighted material in the manuscript before submission.

IJCBR publishes different types of articles

- Original Article (6000 words with $\mathbf{4}$ tables and $\mathbf{4}$ figures, maximum $\mathbf{8}$ display items): Articles with novel findings are the target of IJCBR. Articles presenting a detailed description of a new technique, comparison of existing methods, meta-analyses with comprehensive and in-depth discussion are considered. Papers in a numbered series are not accepted unless all are submitted at the same time.

- Short communications or case study (3000 words with $\mathbf{4}$ display items): Short communications present exceptionally exciting, novel or timely contents are considered. They will be peer-reviewed in the same way as research papers. The references are restricted to 15 .

- Reviews or systematic review (9000 words with $\mathbf{1 0}$ display items): They are invited by the Editorial Board or unsolicited. Review articles have to be contemporary and comprehensive and add information to the knowledge. Sharp critical analyses of novel data or concepts are encouraged. When relevant, a statistical analysis of data and a meta-analysis approach are recommended.

- Opinion papers, letter to the editor or comment to the editor (1500 words with $\mathbf{2}$ display items): They are submitted by invitation of the Editorial Board. They are short papers, which aim to inform scientists, industry, and the public and policymakers about cutting-edge issues in research or the impact of research. They reflect the opinion of their authors who bear full responsibility of the published paper. The references are restricted to 10 .

- Conference/Symposium papers: The journal will consider for publication the results of original work and critical reviews that are presented at conferences/symposia. Symposium organizers who wish to publish bundles of papers from a symposium/conference in IJCBR should first contact the Editor-in-Chief of the IJCBR (EACR@unv.tanta.edu.eg) for agreement. Supplementary material can be proposed and will be made available online. The responsibility for the preparation of a paper in a form suitable for publication lies with the author.

- Thesis: IJCBR can publish the summary and abstract of Master and PhD theses in a special issue.

English: Good quality of written English is required. Spelling may be in British or American English but must be consistent throughout the paper. Care should be exercised in the use of biological terminology that is ill-defined or of local familiarity only. We recommend that authors have their manuscripts checked by an English language native speaker before submission.

Manuscript layout: Manuscripts should be prepared using a standard word processing program and presented in a clear readable format with easily identified sections and headings. The manuscript layout is based on the following directions.

- The main text contains Title, Abstract, Keywords, Introduction, Material and Methods, Results, Discussion, References, Tables, figures.

- The title needs to be concise and informative. Use bold, with an initial capital for the first word only and for words that ordinarily take capitals.

- Short (running) title (max 80 characters including spacing).

- The article text should be typed with double line spacing with wide margins $(2.5 \mathrm{~cm})$.

- The lines must be continuously numbered; the pages must also be numbered.

- Font Calibri 12 should be used for the text, and 12 for the tables, figure legends and references.

- The sections should typically be assembled in the following order:

- Title page contains title, authors' names, full affiliations, acknowledgements and the corresponding author's contacts and Short title.

Abstract (max 250 words, single paragraph): The abstract should be complete and understandable without citation, references, table, or figure. Use structured abstract: Background, Aim, Materials \& Methods, Results and Conclusion. The context and the rationale of the study are presented succinctly to support the objectives. The experimental methods and main results are summarized but should not be overburdened by numerical values or probability values. The abstract ends with a short and clear conclusion. 
Keywords: Up to five short and specific keywords should complement the title with respect to indicating the subject of the paper in alphabetic order.

Introduction: The introduction briefly outlines the context of the work, presents the current issues that the authors are addressing and the rationale to support the objectives, and clearly defines the objectives.

Material and methods: Material and methods should be described in sufficient details so that others can repeat the experiment. Reference to previously published work may be used to give methodological details, provided that said publications are readily accessible and in English. The code of ethics should be followed for all experiments use animals or human samples.

Statistical analysis of results: The statistical design and the models of statistical analysis must be described, as well as each of the statistical methods used. Sufficient statistical details must be given to allow replication of the statistical analysis. The experimental unit should be defined (e.g., individual or group of animals).

Results: Data are presented as tables and figures. Brief description of the results for each table and figure should be presented. Unpublished data can be mentioned when necessary.

Discussion: Should be separate from the Results section and should focus only on intra- and inter-data discussion (the data in the results section) as well as with the relative data in the literature. Don't repeat information already presented in the Introduction section. Start the first paragraph in the Discussion with a paragraph stating the rationale behind the study, the objectives, and the main findings. End Discussion with a short conclusion.

Acknowledgements: In this section, the authors may acknowledge (briefly) their support staff.

Conflict of interest: All papers with a potential conflict of interest must include a description/explanation in a separate heading.

Funding details: The authors should state the source of findings of the study (with research funder and/or grant number). If no fund, the authors should state that the study is self-funded.

\section{References}

Citation of references: In the text, references should be cited by the author(s) surname(s) and the year of publication (e.g. Salem, 2020). References with two authors should be cited with both surnames (e.g. Salem and Meshrif, 2021). References with three or more authors should be cited with the first author followed by et al. (in italics; e.g. Salem et al., 2021). Names of organizations used as authors (e.g. Food and Drug Administration) should be written out in full in the list of references and on the first mention in the text. Subsequent mentions may be abbreviated (e.g. FDA).

- List of references. Literature cited should be listed in alphabetical order by authors' names. It is the author's responsibility to ensure that all references are correct. All authors should be written and so the full journal name.

- $\quad$ References from journal articles are formatted in APA as this example: Al-Amoudi WM (2018). Toxic effects of Lambdacyhalothrin on the rat thyroid. Involvement of oxidative stress and ameliorative effect of ginger extract. Toxicology Reports, 5: 728-736.

- $\quad$ References from books or official reports are formatted as this example. Kebreab E, Dijkstra ANM, Bannink A, Gerrits WJJ, \& France J (2006). Nutrient digestion and utilization in farm animals. CABI Publishing. Wallingford, UK.

- References from chapters or parts of books are formatted as this example. Nozière $P, \&$ Hoch $T$ (2006). Modelling fluxes of volatile fatty acids from rumen to portal blood. In: Nutrient digestion and utilization in farm animals (Kebreab E, Dijkstra ANM, Bannink A, Gerrits WJJ \& France J, eds.), pp. 40-47. CABI Publishing. Wallingford, UK.

Tables: The data should be presented in tables or in graphs, not both.

- Each table should be placed on a separate page at the end of the main text.

- Tables are numbered consecutively using Arabic numbering. They are referred to as Table 1 , Table 2, etc., with capital ' $T$ ', no italics

- $\quad$ Each table has its explanatory caption. The caption is sufficient to permit the table to be understood without reference to the text.

- Abbreviations used in tables/figures have to be defined either as footnotes or in the caption.

\section{Figures}

- $\quad$ Package the figures in a single PowerPoint file. Each figure in a separate slide.

- Figure size should be readable in a width of approximately 8-175 $\mathrm{mm}$ (i.e. the maximum size of printing over two columns).

- Ensure that the font size is large enough to be readable at the final print size, use Calibri font to ensure that they are consistent throughout the figures.

- $\quad$ The figures should preferably be provided as TIFF or EPS files.

- The resolutions of figures must be at least $300 \mathrm{dpi}$.

- Preparation of images for a manuscript: For guidance, we refer to the Journal of Cell Biology's instructions to authors (http://jcb.rupress.org/site/misc/ifora.xhtml\#image_aquisition).

- If a cropped image is included in the main text of a paper (e.g. a few lanes of a gel), display the full original image, including the appropriate controls, the molecular size ladder and/or the scale as relevant, as a single figure in a Supplementary Material file to facilitate peer-review and for subsequent online publication.

- Supplementary material is submitted along with the main manuscript in a separate file and identified at uploading as "Supplementary File - for Online Publication Only" The title of the article is included at the top of the supplementary material.

Corresponding author's guidelines: Upon acceptance the corresponding author is required to send his/her recent formal photo to be attached to the front page of the article. 


\title{
International Journal of Cancer \& Biomedical Research
}

(IJCBR) Online ISSN 2682-2628

\author{
Editor-in-Chief \\ Mohamed Labib Salem, PhD \\ Tanta University, Egypt
}

\begin{tabular}{l} 
EACR Board \\
\hline Nehal Elmashad, MD \\
Tanta University, Egypt \\
Nabil Mohy Eldin, PhD \\
Kafrelsheikh University, Egypt \\
Doaa Al-Ghareeb, PhD \\
Alexandria University, Egypt \\
Abdel-Aziz Zidan, PhD \\
Damanhour University, Egypt
\end{tabular}

\begin{tabular}{l} 
Managing Editor \\
\hline Wesam Meshrif, PhD \\
Tanta University, Egypt \\
Sohaila Galal, PhD \\
Tanta University, Egypt \\
Production and Contact \\
\hline Hamdi Kandil \\
Tanta University, Egypt \\
Email: ljcbr100@gmail.com
\end{tabular}

\section{Advisory Board}

Alberto Montero, MD

Taussig Cancer Center, Cleveland,

USA

Yi Zhang, MD

Zhengzhou University, China

Mark Robunstein, Ph D

Medical University of South

Carolina, USA

Mohsen Farid, Ph D

Derby University, USA

Natarajan Muthusamy, Ph D

Ohio State University, USA

Hideki Kasuya, MD

Nagoya University, Japan

Sherif El-Khamisy, Ph D

Sheffield University, UK

Mohamed Ghanem, Ph D

Kafr Elshikh University, Egypt

Sayed Bakry, Ph D

Alazhar University, Egypt

Sameh Ali, Ph D

Nationa Liver Institute, Egypt

Gamal Badr, Ph D

Assuit University, Egypt

Nadia Hamdy, Pharm D

Ain Shams University, Egypt

\section{Editorial Board}

\section{Clinical studies}

Hesham Tawfik, MD

Tanta University, Egypt

Mohamed Attia, MD

Tanta University, Egypt

Mohamed Elshanshory, MD

Tanta University, Egypt

Essam Elshiekh, MD

Tanta Cancer Center, Egypt

Rasha Eraky, MD

Tanta University, Egypt

Shaima Abou-Kjatwa, MD

Tanta University, Egypt

Marcela Diaz, MD

Cleveland Clinic Foundation, USA

Mohamed Abou-El-Enein, MD

Charité Universitätsmedizin Berlin,

Germany
Alaa Eldin Almostafa, MD

McGill University, Canada

Olfat Gadallah, MD

Tanta University, Egypt

Nagla Sarhan, MD

Tanta University, Egypt

Naglaa Fathy, Pharm D

Zagazik University, Egypt

Mohamed Salama, MD

Mansoura University, Egypt

Mona Marie, MD

Alexandria University, Egypt

Preclinical studies

Mostafa El-Sheekh

Tanta University, Egypt

El-Refai Kenawy, Ph D

Tanta University, Egypt

Mohamed Noureldin, Ph D

Banaha University, Egypt

Yousry Albolkiny, Ph D

Tanta University, Egypt

Elsayed Salim, Ph D

Tanta University, Egypt

Shengdian Wang, Ph D

Chinese Academy of Sciences,

China

Sabry El Naggar, Ph D

Tnata Univesity, Egypr

Faris Alenzi, Ph D

Prince Sattam bin Abdulaziz

University, KSA

Ibrahim El-Sayed, Ph D

Menoufia University, Egypt

Tarek Aboul-Fadl, Ph D

Assiut University, Egypt

Rabab Khairat, Ph D

National Research Center,

Giza, Egypt

Wael Lotfy, Ph D

Alexandria University, Egypt

Ashraf Tabll, Ph D

National Research Center, Egypt

Nahla Shoukry, Ph D

Suez University, Egypt
Medhat Eldenary, Ph D

Tanta University, Egypt

Azza Hasan, Ph D

Menufia University, Egypt

Nanees Gamal Eldin, Ph D

Tanta University, Egypt

Mohamed Mansour, UK

Sabbah Hammoury, Ph D

Alexandria Ayadi Almostaqba

Oncology Hospital, Egypt

Nehal Aboulfotoh, Ph D

Zewail City for Science and

Technology, Cairo, Egypt

Amir Elkhami, Ph D

Galaxo, San Francisco, USA

Ahmed Alzohairy, Ph D

Zagazi University, Egypt

Wgady Khalil, Ph D

National Research Center, Egypt

Amr Amin, Ph D

United Arab Emirates

University, UAE

AbdelRahman Zekri, Ph D

National Cancer Institute, Egypt

Hussein Khamis, Ph D

Alexandria University, Egypt

Magdy Mahfouz, Ph D

Kafr Elsheikh University, Egypt

Ehab Elbedewey, Ph D

Tanta University, Egypt

Abeer Badr, Ph D

Cairo University, Egypt

Mamdooh Ghoneum, Ph D

Charles Drew University of

Medicine \& Science, USA

Haiam Abou Elela, Ph D

National Institute of Oceanography and Fisherie, Egypt

Maha EL-Demellawi, Ph D City for Scientific Research \&

Technology Applications, Egypt

Desouky Abd-El-Haleem, Ph D

City for Scientific Research \&

Technology Applications, Egypt 